\title{
ANALISIS PENGUCAPAN DAN PEMBENTUKAN KATA KEANUAGL DALAM INSTA STORY SELEBGRAM
}

\author{
ANALYSIS OF SPEECH AND FORMATION OF KEANUAGL WORDS \\ IN SELEBGRAM INSTA STORY
}

\author{
Lailis Saadah $^{1}$, Afifah Wulandari ${ }^{2}$, Ummi Fatmawati $^{3 *}$ \\ ${ }_{1,2,3}$ Institut Agama Islam Negeri Surakarta \\ *Corresponding Author: fatmawatiumy99@gmail.com \\ Informasi Artikel:
}

Dikirim: 3/1/2020; Direvisi: 15/1/2020; Diterima: 25/1/2020

\begin{abstract}
The speech of language by someone is idiosyncratic or distinctive. Using a qualitative descriptive method, this study analyzed Keanuagl's pronunciation of the Insta Story Selebgram (ISS). Research data, in the form of words spoken by Keanuagl, were collected using the observation, note and record method. Data were analyzed by prescriptive analytic, meaning that they were compared with what should have been spoken. The results of the research data analysis are presented informally. This study found that phonological deviations were often carried out in the pronunciation or pronunciation performed by Keanuagl in the ISS. Some of the phoneme pronouncements done by Keanuagl do not match the proper pronunciation of the phonemes. In his speech, Keanuagl often performs phoneme removal, phoneme addition, and phoneme exchange.
\end{abstract}

Keywords: language, morphology, phonology, speech errors, word formation errors

\begin{abstract}
Abstrak
Ucapan bahasa oleh seseorang bersifat idiosinkretis atau khas. Menggunakan metode deskriptif kualitatif, penelitian ini menganalisis pengucapan yang dilakukan oleh Keanuagl pada Insta Story Selebgram (ISS). Data penelitian, berupa cara penuturan katakata yang dikemukakan oleh Keanuagl, dikumpulkan menggunakan metode simak, catat, dan rekam. Data dianalisis secara preskriptif analitik, artinya diperbandingkan dengan yang seharusnya diucapkan. Hasil analisis data penelitian disajikan secara informal. Penelitian ini menemukan bahwa penyimpangan fonologis sering dilakukan pada pengucapan atau pelafalan yang dilakukan oleh Keanuagl dalam ISS. Pengucapan fonem yang dilakukan oleh Keanuagl ada yang tidak sesuai dengan pengucapan fonem yang seharusnya. Dalam tuturannya, Keanuagl sering melakukan penghilangan fonem, penambahan fonem, dan penukaran fonem.
\end{abstract}

Kata kunci: berbahasa, morfologi, fonologi, kesalahan ucapan, kesalahan pembentukan kata 


\section{PENDAHULUAN}

Bahasa merupakan bagian yang penting dalam peradaban, karena merupakan salah satu sarana komunikasi untuk saling berbagi informasi, menuangkan gagasan atau pemikiran, serta menjadi faktor pendukung hubungan sosial. Menurut Kridalaksana (2008:24) bahasa merupakan sistem lambang bunyi yang digunakan oleh masyarakat sebagai sarana kerja sama, berinteralsi dan pengembangan diri. Trudgill (1974:13) menyatakan bahwa selain sebagai sara mengomunikasikan informasi, bahasa juga sebagai sarana yang penting untuk membangun dan mempertahankan hubungan antara makluk hidup. Bahasa adalah cerminan pikiran manusia. Bahasa tidak mungkin ada tanpa pikiran, begitu pula sebaliknya (Apriani, 2016:11). Dalam berbahasa terdapat empat keterampilan, yakni menyimak, membaca, menulis, dan berbicara. Berbicara merupakan kemampuan seseorang dalam mengucapkan kata-kata untuk mengekspresikan, menyatakan, serta menyampaikan gagasan dan perasaannya secara lisan kepada orang lain. Hal tersebut berkesinambungan dengan linguistik ,yaitu dalam lingkup fonologi.

Fonologi memiliki keterkaitan erat dalam mempelajari bahasa sebagai alat komunikasi. Fonologi merupakan cabang linguistik yang mempelajari tentang bunyi-bunyi bahasa yang diproduksi oleh alat ucap manusia. Menurut Kridalaksana (2008), fonologi adalah bidang dalam linguistik yang menyelidiki bunyi-bunyi bahasa menurut fungsinya. Jadi, dalam fonologi dibahas tentang bagaimana bahasa itu dapat dikatakan oleh manusia sesuai dengan kaidah di pengucapan dalam bahasa Indonesia. Kesalahan fonologis, yaitu kesalahan pada tataran bunyi, baik pada tataran kata, frasa, klausa atau kalimat. Kesalahan ini hanya terjadi dalam penggunaan bahasa lisan, terutama secara produktif (berbicara).

Adapun cabang linguistik yang membahas mengenai pembentukan kata, yaitu morfologi. Rohmadi (2009:1) menjelaskan bahwa linguistik adalah ilmu tentang bahasa. Selain itu, linguistik merupakan penyelidikan bahasa secara ilmiah. Oleh karena itu, linguistik mempunyai peranan yang sangat penting dalam kehidupan manusia. Namun, bahasa bukan satu-satunya alat komunikasi manusia karena juga dikenal alat komunikasi isyarat, simbol, kode, dan bunyi yang semua itu akan bermakna setelah diterjemahkan ke dalam bahasa manusia. Dengan demikian, bahasa disebut sebagai alat komunikasi terpenting bagi manusia. Verhaar (1984:54) berpendapat bahwa morfologi adalah bidang linguistik yang mempelajari susunan bagian kata secara gramatikal. Kridalaksana (2008:129) berpendapat bahwa morfologi yaitu bidang linguistik yang mempelajari morfem dan kombinasi-kombinasinya, bagian dari struktur bahasa yang mencakup kata dan bagian kata (morfem). Dari definisi tersebut dapat disimpulkan bahwa morfologi merupakan bidang linguistik yang mengkaji hubungan antara morfem yang satu dengan morfem yang lain untuk membentuk sebuah kata.

Pada era globalisasi bahasa mulai berkembang melalui media sosial, salah satunya adalah Instagram, banyak orang yang berlomba-lomba menunjukkan jati dirinya melalui media sosial tersebut. Adapun di dalam Instagram terdapat fitur instastory yang merupakan tempat untuk berbagi cerita, berbagi informasi, tempat karya atau ekspresi seseorang, dalam bentuk foto maupun video dan lain sebagainya. Oleh karena itu, dalam penyampaian informasi, bahasa yang digunakan harus baik dan benar, serta mudah dibaca dan dimengerti oleh pengguna media sosial lainnya atau bisa disebut 'netizen'. Penggunaan bahasa dalam 
sosial media khususnya Instastory pada Instagram biasanya terdapat beberapa kesalahan. Bahasa yang digunakan biasanya tidak berstruktur dan tidak baku atau ejaan yang digunakan tidak tepat. Selain mengesampingkan pedoman kaidah-kaidah penulisan bahasa yang benar, instastory hanya mengedepankan eksistensi, keunikan dan cenderung menggunakan bahasa gaul yang memungkinkan netizen untuk tertarik melihatnya. Padahal bahasa yang baik dan benar sangat penting dalam penyampaian informasi. Hal itu dapat menunjang karakteristik seseorang dan informasi yang disampaikannya untuk dapat diterima oleh masyarakat dengan baik dan jelas. Permasalahan yang mendasar dalam penelitian ini adalah bagaimanakah wujud kesalahan berbahasa bidang fonologi pada instastory oleh selebgram Keanuagl? Bagaimanakah pengucapan setiap fonem dan bentukan kata pada pada tuturan instastory yang dilakukan oleh selebgram bernama Keanuagl?

Keanuagl adalah seorang selebgram yang terkenal atau viral, akibat tingkahnya yang lucu dalam berbicara dan cenderung blak-blakan, beberapa konten Keanuagl adalah tanya jawab atau QnA dalam instastorynya, di situlah jawaban-jawaban Keanuagl yang kocak membuat ia dianggap sebagai seorang yang lucu. Sebelum terkenal dulunya ia adalah seorang penjaga kantin dan ojek online, ia termotivasi bekerja keras untuk merubah perekonomiannya menjadi semakin baik. Saat ini Keanuagl memiliki 1,7JT follower (pengikut), gayanya yang khas dan bicaranya yang lucu membuat ia mampu menarik pengikut sebanyak itu.

Dari fenomena tersebut, penelitian ini terfokus pada kesalahan-kesalahan fonologis dan morfologis yang terjadi pada instastory selebgram Keanuagl, lengkap dengan klasifikasi kesalahan serta mendeskripsikan kesalahan dalam berbahasa serta mengindentifikasi dan menganalisis kesalahan berbahasa. Tujuan penelitian ini mendeskripsikan bentuk kesalahan berbahasa, kesalahan fonologi, yang terdapat pada sosial media Instagram instastory, dan mendeskripsikan tuturan kalimat yang diucapkan dalam instastory selebgram Keanuagl. Sebelumnya, penelitian kesalahan berbahasa pernah dilakukan oleh Indihadi (2011) yang hasilnya dimuat dalam jurnal yang berjudul Analisis Kesalahan Berbahasa Bidang Morfologi dalam Wacana Jual Beli Daring di Instagram. Adapun yang membedakan penelitian ini yakni penelitian ini lebih memfokuskan pada teori bahasa, yakni fonologi dan morfologi. Analisis kesalahan berbahasa bertujuan mengetahui serta menjawab strategi berbahasa agar sesuai kaidah. Melalui hal tersebut kita dapat memilah dan menemukan apakah bahasa tersebut benar maupun salah.

\section{METODE}

Penelitian ini menggunakan metode deskriptif kualitatif, yang bersifat actual, dengan interpretasi data yang telah ditemukan, kemudian dianalisis menggunakan teori yang sesuai dengan fenomena yang ditemukan. Desain penelitian yang digunakan adalah analisis isi (content analysis), karena data yang digunakan berupa data verbal, yaitu tuturan oleh selebgram Keanuagl dalam instastorynya. Selain itu, alasan menggunakan desain analisis isi karena jenis penelitian ini mengungkap dan menggambarkan jenis kesalahan bahasa yang timbul ketika subjek penelitian, yaitu Keanuagl mengucapkan kata-kata. Adapun metode pengumpulan data yang digunakan oleh peneliti adalah metode simak dengan teknik simak, teknik catat dan teknik rekam melalui media sosial Instagram. 
Penelitian ini mengkaji penggunaan bahasa yang dilakukan oleh para informan, pengamatan ini tentunya memerlukan teknik untuk mengetahui wujud fonem-fonem tersebut (misalnya dengan memanfaatkan fonetik artikulatoris, bentuk kata yang diucapkan) tidak hanya dengan mendengarkan suatu bunyi-bunyi yang diperoleh oleh informan tersebut. Akan tetapi, peneliti juga harus memerhatikan atau melihat bagaimana bunyi itu dapat dihasilkan. Kemudian teknik selanjutnya dalam metode simak, cakap, kemudian teknik rekam. Adapun metode lain yang digunakan adalah metode analisis kesalahan yang bertujuan untuk mengetahui letak kesalahan ucapan dan mengklasifikasikan kesalahan-kesalahan yang dibuat selebgram Keanuagl.

\section{HASIL DAN PEMBAHASAN}

Untuk mengetahui kesalahan pengucapan bahasa atau kesalahan fonologis dan kesalahan pembentukan kata yang dilakukan oleh Keanuagl dalam ISS, kita perhatikan kutipan data dan analisisnya berikut ini.

Data 1. "Makenye jangan ngarepin dibales bae-bae aje kalo lo nanya begini jatohnya lo nggak pernah iklas jelek, nggausah maen nggausah ngasi-ngasi deh..."

Analisis kesalahan yang terdapat pada data tersebut dapat diuraikan sebagai berikut. Pada kata 'makenye' bentuk kesalahannya terletak pada pemakaian fonem [e] yang seharusnya adalah [a], karena kata yang umum digunakan oleh penutur bahasa Indonesia adalah kata "makanya”. Selanjutnya, pada kata 'ngarepin' juga terdapat kesalahan berbahasa yang merupakan transformasi dari kata 'mengharapkan', kata 'dibales' juga terdapat pergantian fonem [e] yang seharusnya adalah fonem [a] yaitu 'dibalas', kemudian pada kata 'bae-bae' juga merupakan transformasi dari kata 'baik-baik', terdapat pergantian fonem [i] menjadi [e] dan penghilangan fonem [k]. kemudian pada kata 'ngasi-ngasi' juga merupakan transformasi dari kata 'ngasih', terdapat penghilangan fonem [h]. Berikutnya kita perhatikan kutipan data di bawah ini.

Data 2. "Trus tujuan lo pacaran apaan jadi keker lo pen kasur apa pen kering, mau tinju lo ame die? deh-deh gue minta ampun deh.

Analisis kesalahan terletak pada transformasi kata "terus" menjadi 'trus'. Dalam kalimat tersebut ada penghilangan fonem [e]. Kemudian pada kata 'pen' merupakan transformasi kata "pengen", terdapat penghilangan kata atau kesrempetnya kata 'ngen', kemudian pada fonem ' ame die' merupakan bentuk kesalahan pemakaian bentuk [e] seharusnya yaitu [a] dan juga ada penghilangan fonem [s] dalam transformasi dari kata "sama dia".

Data 3. "Kak ken transfer duit cepek aje, apa dah, lu kenape? Udeh ngemis cephek lagi, sejuthak kek hemmm nggigil gue". 
Analisis kesalahan pada data tersebut adalah dalam kalimat tersebut pada kata 'aje' merupakan transformasi dari kata 'aja', terdapat pergantian fonem [a] menjadi [e], kemudian pada kata 'kenape' juga merupakan transformasi dari kata 'kenapa', pada fonem [a] diganti [e]. Pada kata 'udeh' juga transformasi dari kata 'udah' juga terdapat pergantian fonem [a] yang diganti fonem [e]. Pada kata 'cepek' juga terdapat tambahan/sisipan fonem [h] pada pengucapannya, sehingga terdengar 'cephek'. Pada kata 'sejuta' juga terdapat sisipan dan tambahan fonem $[\mathrm{h}]$ ditengah dan fonem [k] diakhir, sehingga terdengar 'sejuthak'.

Data 4. "Aku sayang keanu, percaya deh ge bisa sayang sama gue, gue nggak kenal lo siape? Samak lebpih kali gue, tapi adem aje ngeliat nye, koh lem adem liat gue jangan ngadi-ngadi deh.... aaaaa candak".

Analisis kesalahannya terletak pada transformasi kata 'Ge' merupakan bentuk kata "gue" dalam kalimat tersebut ada penghilangan fonem [u]. Kemudian pada fonem 'siape' merupakan bentuk kesalahan, pemakaian fonem [e] yang seharusnya adalah [a] merupakan bentuk dari kata "siapa" dan fonem 'aje' menggunakan pemakaian fonem [e] seharusnya adalah [a], kemudian pada transformasi kata 'ngeliat' merupakan bentuk kata "ngelihat" dalam kata tersebut ada penghilangan fonem [h] dan kata 'nye' merupakan bentuk kesalahan pemakaian fonem [e] seharusnya adalah [a] merupakan bentuk dari kata "nya", kemudian pada kata 'ngadi-ngadi' merupakan transformasi dari kata "mengada-ngada" yang merupakan penghilangan fonem [me] dan terdapat pergantian fonem [a] menjadi [i] dan kata 'candak' merupakan bentuk dari kata "bercanda" dalam kalimat tersebut ada penghilangan kata [ber] dan ketambahan fonem $[\mathrm{k}]$ yang merupakan kalimat tersebut menjadi racuh.

Data 5. "Ya allah properthi kebawak, gue dadijalan nyantae-nyantae kan, ni gimana buna ni, urusan deh ah-ah pake nyangkut dipala gue ni bando".

Pada kata "properthi" ada tambahan fonem /h/ yang seharusnya jika disesuaikan dengan KBBI tidak ada penambahan fonem /h/. Dalam kata "kebawak" ada penambahan fonem /k/ di akhir kalimat yang tidak sesuai dengan kaidah kebahasaan. Lalu, ada kalimat yang di sambung menjadi satu yaitu "dahdijalan" seharusnya "sudah di jalan". Kata ulang "nyantae-nyantae" merupakan kata ulang yang tidak sesuai dengan kaidah kebahasaan, yang harusnya adalah "santai-santai", fonem yang seharusnya /s/ diganti dengan [ny] sedangkan fonem /i/ dalam kalimat tersebut diganti dengan fonem /e/. Lalu, penghilangan fonem /i/ pada kata "ini", dan penghilangan fonem /h/ pada kata "nih". Kata "dipala" harusnya yang benar adalah "di kepala".

Data 6. "Gue lagi pake dari bintangisty ini baju tidur ini sumpah frendly banget karena bahanya endul banget".

Dalam data ini terdapat kata "ini" dua kali yang membuat kalimat menjadi tidak efektif. Kata "endul” merupakan kata prokem yang artinya "enak". 
Data 7. "lu tau nih si kampret tukang boong nih laghi lu adepin, orang kabur".

Kata "boong"pada kalimat tersebut mengalami penghilangan fonem $/ \mathrm{H} /$, pada kata "laghi" mengalami penambahan fonem /h/ pada pengucapan Keanu, sedangkan pengucapan kata "adepin" yang benar adalah "hadapi".

Data 8. "Kak tips cepet kaya dong, korupsyi udeh ini aman sekarang, boleh nggak sih gue ngomong gini? Kurup lah giyla hari gyini".

Dalam data ini ditemukan adanya penambahan fonetis [y] pada kata "korupsyi", fonem /a/ diganti fonem /e/ pada kata "udeh", penambahan fonetis [y] pada kata "gila" dan "gini" menjadikan pengucapanya terdengar gemulai.

Data 9. "Kok dia tiba-tiba menjauh gimana nih, mandi sikat gigi mulut lu bau lambhung".

Dalam data 9 ini terdapat fonetis [ $\left.{ }^{\mathrm{h}}\right]$ pada kata "lambhung".

Data 10. "Nape lo rekam-rekame, gue gi nonton cinta begitu indah, jangan ketawaketawa aja loh, udeh nonton di Witipi udah gratis ada subtitle bahasa indonesianya lagi, dan loh jangan ngadi-ngadi deh, lo nonton nih Witipi hibran sia terbaik, dijamin ketagihan”.

Pada data ini terdapat transformasi kata "nape" yang merupakan bentuk kata "kenapa". Kemudian ada bentuk kesalahan pemakaian fonem [e] yang seharusnya adalah [a] merupakan bentuk dari kata "kenapa", Adanya penambahan fonetis [ e ] pada kata "rekam", ada transformasi kata "gi" merupakan bentuk kata "lagi", fonem /a/ diganti fonem /e/ pada kata (udeh), kata "Witipi" yang seharusnya "WeTV" sehingga tidak sesuai dengan kaidah, kemudian pada kata 'ngadi-ngadi' merupakan transformasi dari kata "mengada-ngada" yang merupakan penghilangan fonem [me] dan terdapat perubahan fonem [a] menjadi [i], Kata "hibran" pada kalimat tersebut mengalami penghilangan fonem / u/ dan kata "sia" mengalami penghilangan fonem/a/.

Data 11. "Heh gila lo Qienne tiap hari minta Qienne minta semangat, darah rendah lo jan kyak orang tipes lo, kek gak dak kehidupan tau gak".

Pada data 11 terdapat kata "Qienne" yang merupakan merupakan varian dari bentuk kata "Q \& A" sehingga tidak ada pemaknaan dalam kata tersebut dan tidak sesuai dengan kaidah kebahasaan, dan pada transformasi kata "jan" merupakan bentuk kata "jangan". Kata "kyak" pada kalimat tersebut mengalami penghilangan fonem / a/, dan ada penambahan fonem [ k ]. Kata "dak" seharusnya yang benar adalah "ada", sehingga ada penghilangan fonem /a/ dan ditambahkan fonem /k/ di akhir kata. 
Data 12. "Pokoknya buat kalian semua yang keteknya item lehernya item pakek ya, biar makin pedek".

Kata "item" pada kalimat tersebut mengalami penghilangan fonem / H/, pada kata "hitam" dan juga mengalami perubahan fonem [a] menjadi [e]. Berikut adalah tabel kesalahan pengucapan yang dilakukan oleh Keanuagl dalam ISS, yang ditemukan dalam penelitian ini.

Tabel 1. Kesalahan Fonologi

\begin{tabular}{|c|c|c|c|}
\hline No. & Kesalahan fonologi & Data & $\begin{array}{c}\text { Jumlah } \\
\text { Kesalahan }\end{array}$ \\
\hline 1. & $\begin{array}{l}\text { Pemakaian fonem [e] } \\
\text { seharusnya adalah [a] }\end{array}$ & $\begin{array}{l}\text { Makanya - makenye } \\
\text { Dibalas - dibales } \\
\text { Ame - sama } \\
\text { Dia - die } \\
\text { Aja - aje } \\
\text { Kenapa - kenape } \\
\text { Udah - udeh } \\
\text { Siapa - siape } \\
\text { Nya - nye }\end{array}$ & 9 \\
\hline 2. & Fonem [a] menjadi [e] & Hitam - item & 1 \\
\hline 3. & fonem [i] menjadi [e] & Baik-baik menjadi bae-bae & 1 \\
\hline 4. & Penghilangan fonem [k] & Bae-bae (baik-baik) & 1 \\
\hline 5. & penghilangan fonem [h] & $\begin{array}{l}\text { Ngasi - ngasih } \\
\text { Ngeliat - ngelihat } \\
\mathrm{Ni} \text { - nih } \\
\text { Boong - bohong } \\
\text { item - hitam }\end{array}$ & 5 \\
\hline 6. & Penghilangan fonem [s] & Sama dia - ame die & 1 \\
\hline 7. & penghilangan fonem [e] & Terus - Trus & 1 \\
\hline 8. & tambahan/sisipan fonem $[\mathrm{h}]$ & $\begin{array}{l}\text { Capek - caphek } \\
\text { Sejuta - sejutha } \\
\text { Cepek - cephek }\end{array}$ & 3 \\
\hline 9. & penghilangan fonem $[\mathrm{u}]$ & Gue - Ge & 1 \\
\hline 10. & Penambahan fonem $[\mathrm{k}]$ & $\begin{array}{l}\text { Sejuta - Sejuthak } \\
\text { Bercanda - Candak } \\
\text { Kebawa - Kebawak } \\
\text { Ada-Dak }\end{array}$ & 3 \\
\hline 11. & penambahan fonetis $[\mathrm{y}]$ & $\begin{array}{l}\text { Korupsi - Korupsyi } \\
\text { Gila - Giyla }\end{array}$ & 2 \\
\hline
\end{tabular}


Analisis Pengucapan dan Pembentukan Kata Keanuagl dalam Insta Story Selebgram (Lailis Saadah, Afifah Wulandari, Ummi Fatmawati)

Tabel 2. Kesalahan Morfologi

\begin{tabular}{llll}
\hline No. & Jenis kesalahan & \multicolumn{1}{c}{ Kata yang salah } & Penulisan yang benar \\
\hline 1. & \multirow{2}{*}{ Prefiks me- } & Ngarepin & Mengharapkan \\
& & Ngasi-ngasi & Mengada-ngada \\
& & Ngigil & Menggigil \\
& & Ngelihat & Melihat \\
2. & Prefiks ber- & Nyantae-nyantae & Bersantai-santai \\
\hline
\end{tabular}

Analisis data dalam penelitian ini dilakukan dengan mengklasifikasikan kata yang teridentifikasi sebagai bentuk kesalahan berbahasa bidang morfologi yang diketahui dengan kata yang bercetak miring.

\section{Penulisan Prefiks me-}

Analisis kesalahan

"Makenye jangan ngarepin dibales"

Imbuhan ng- merupakan serapan bahasa jawa, maka pemakaian yang tepat adalah imbuhan prefiks me-, yaitu mengharapkan

"nggausah maen nggausah ngasi-ngasi deh"

Kata 'ngasi-ngasi' berasal dari kata 'ngada-ngada' akan tetapi lebih tepatnya diberi imbuhan prefiks me-, yaitu mengada-ngada

"sejuthak kek hemmm nggigil gue"

Pada kata 'nggigil' kurang tepat, lebih tepatnya menggunakan imbuhan prefiks mesehingga menjadi menggigil

" tapi adem aje ngeliat nye"

Pada kata 'ngeliat' sebaiknya menggunakan kata 'melihat' dengan adanya tambahan prefiks me- kata tersebut menjadi baik dan juga benar.

\section{Prefiks ber-}

" gue dadijalan nyantae-nyantae kan"

Pada kata 'nyantai-nyantai' kurang tepat, seharusnya menggunakan kata 'bersantaisantai' sehingga ada imbuhan prefiks ber- yang merupakan bentuk kata kerja.

\section{SIMPULAN}

Dari penelitian yang telah dilakukan dapat disimpulkan bahwa peneliti menemukan beberapa kesalahan, yakni kesalahan dalam pengucapan (fonologis) dan kesalahan dalam pembentukan kata (morfologis) yang dilakukan oleh Keanuagl pada Insta Story Selebgram . Berdasarkan analisis data tentang kesalahan berbahasa tersebut, kesalahan-kesalahan bahasa yang dilakukan oleh Keanuagl pada Insta Story Selebgram dapat diklasifikasikan ke dalam 
dua jenis kesalahan, yaitu kesalahan fonologi ditemukan 28 data, dan kesalahan morfologi ditemukan ada 5 data.

Dalam penelitian ini peneliti menemukan beberapa jenis kesalahan, yaitu pengucapan dan penggunaan kata yang dilakukan oleh seorang publik figure. Sehubungan dengan peneliyian ini, peneliti menyarankan kepada peneliti lainnya agar dapat melakukan penelitian jenis kesalahan penggunaan kata yang lain, misalnya, kata ganti oleh orang tersebut.

\section{DAFTAR PUSTAKA}

Apriani, M. 2016. "Analisis Kesalahan Berbahasa Bidang Morfologi oleh Komunitas JualBeli Online di Mataram Nusa Tenggara Barat”. Skripsi. Mataram: Universitas Mataram.

Indihadi, O. 2011. "Kesalahan Berbahasa". (dalam http:/file.upi.rdu/direktori/ dualmodes/pembinaan-bahasa-Indonesia-sebagai-bahasa-kedua-/10bb8. Diakses, 12 Februari 2020.

Kridalaksana, H. 2008. Kamus Linguistik Edisi Keempat. Jakarta: PT. Gramedia Pustaka Utama.

Rohmadi. 2009. Morfologi: Teknik Morfem dan Kata. Surakarta: Yuma Pustaka.

Trudgill, P. 1974. Social Linguistics: An Introduction. Auckland: Watson \& Viney Ltd. Abury, Bucks.

Verhaar, J.W.M. 1984. Asas-asas Linguistik Umum. Yogyakarta: Gadjah Mada University Press. 